\title{
Biofilms from Pathogenic Bacteria in Food Processing Environments: Formation and Preventive Disinfection Procedures
}

\author{
Sarah Hwa In Lee ${ }^{(0)}$, Marina Resende Pimenta Portinari ${ }^{\circledR}$, Carlos Humberto Corassin ${ }^{\circledR}$, Carlos \\ Augusto Fernandes Oliveira*
}

Department of Food Engineering, School of Animal Science and Food Engineering, University of São Paulo, Pirassununga, Brazil

E-mail: carlosaf@usp.br

Received: 28 August 2021; Revised: 6 November 2021; Accepted: 15 November 2021

\begin{abstract}
The ability of some pathogenic bacterial species to form biofilms on surfaces of equipment and utensils is of great concern to the food industry since they represent a continuous source of contamination in food processing environments. In this review, the factors involved in the formation of microbial biofilms are highlighted, along with a discussion on the preventive disinfection procedures recommended to avoid the attachment of microbial cells on surfaces of equipment and utensils in food processing areas. Relevant articles published in the last 10 years (2012-present) were selected in PubMed, Science Direct, and Google Scholar. Methods for assessing the adhesion and biofilm formation ability of strains isolated from surfaces in the food industry environment are also presented.
\end{abstract}

Keywords: biofilms, pathogenic bacteria, surface disinfection, sanitizers, prevention

\section{Introduction}

Biofilms can be defined as complex and highly organized microbial communities formed on biotic or abiotic surfaces, which contain widespread channels in an extracellular polymeric matrix that provide the exchange of nutrients, metabolites, and waste products among the cells $[1,2]$. In food processing environments, biofilms are the major cause for the persistence of bacterial cells on food contact surfaces such as equipment and utensils, hence constituting a continuous source of food contamination [3,4]. Thus, most of the pathogenic or spoilage bacteria in food production systems can be detected on surfaces in the form of planktonic or attached cells, or in community arrangements as a biofilm [5]. For example, there is evidence on the ability of Staphylococcus aureus and Listeria monocytogenes to adhere on the surfaces of food contact materials including stainless steel, rubber, polypropylene, and glass, as well as on the surface of food products [6]. Therefore, the persistence of biofilms formed by pathogenic bacteria on these surfaces is an important cause of food contamination with increased risks of food poisoning outbreaks [3] and negative consequences for public health [6].

In the food industry, factors the environment temperature, $\mathrm{pH}$ of food materials, and availability of their residues can markedly influence the biofilm formation of pathogenic and spoilage bacteria [4, 7-9]. These factors may also increase the resistance of attached cells to disinfection procedures [9-11], which difficult the elimination of the biofilm from food processing environments by conventional cleaning procedures $[1,12]$. The objective of this mini-review was

Copyright (C2021 Carlos Augusto Fernandes Oliveira, et al.

DOI: https://doi.org/10.37256/fse.3120221122

This is an open-access article distributed under a CC BY license

(Creative Commons Attribution 4.0 International License)

https://creativecommons.org/licenses/by/4.0/ 
to highlight the data reported on the formation of microbial biofilms on surfaces in food processing environments, and the relevance of surface cleaning and disinfection strategies on biofilm prevention.

\section{Formation of microbial biofilms on surfaces in the food industry}

Pathogenic bacteria can be incorporated into food processing environments by direct contact with food surfaces from equipment and utensils [13], handlers, and the water used in the cleaning operations or as an ingredient during food manufacture [14]. Several bacterial species are able to produce biofilms on the surface of different materials commonly used in food industries [15]. Bacillus cereus, Escherichia coli, Shigella spp., and S. aureus have been shown to develop biofilms in industrial premises [16, 17], and outbreaks caused by L. monocytogenes, Yersinia enterocolitica, Campylobacter jejuni, Salmonella spp., and E. coli O157:H7 have been linked to biofilms detected in the dairy industry $[1,4,7,12,18,19]$. Bacterial species that form biofilms have genomic variations that determine the characteristics of the biofilm, which can originate different biofilms depending on the conditions [1, 4]. The adhesion, formation process, stage of adhesion, maturation, and the final dispersion of biofilms and consequent persistence of microbial pathogens in the food processing environment may be considered as a response to both biotic and abiotic factors, and the properties of some surfaces simplify microbial binding [20].

The life cycle of biofilm comprises the attachment, proliferation, accumulation, maturation, and dispersal. In addition to the type of bacterial genus and species including genetic variations, the degree of attachment and biofilm formation are highly influenced by extrinsic factors, such as the access to nutrients and the nature of the surface material. Generally, the attachment will occur promptly on surfaces that are rougher, more hydrophobic, and crusted. In particular, surfaces that have direct contact with food materials have a favoring effect on the level of attachment and biofilm formation [20], due to the interaction between the microbial cells and the amount of food residues on surfaces. Moreover, the attachment of microbial cells onto a given surface can be modulated by physical properties, such as electrostatic charges, hydrophobicity, and roughness of the surface [21]. These properties are highly variable among the materials commonly used in the food industry, such as stainless steel, rubber, polypropylene, and silicone, as presented in Table 1. Stainless steel is one of the most employed materials in the construction of food equipment, mainly because of its high durability and resistance to corrosion [17]. However, most of the pathogens involved in food-borne diseases can adhere to the majority of materials encountered in food production plants, and several reports have demonstrated the ability of bacterial cells to produce biofilms on the aforementioned materials [5, 22, 23].

Table 1. Materials commonly used in the food industry, on which pathogenic bacteria have been reported to attach and develop biofilms

\begin{tabular}{|c|c|c|c|}
\hline Type of surface & Main characteristics & Pathogenic bacterial species & Reference \\
\hline Stainless steel & $\begin{array}{l}\text { Highly hydrophobic and resistant; } \\
\text { low roughness of the surface }\end{array}$ & L. monocytogenes, S. aureus & [24] \\
\hline Rubber & $\begin{array}{l}\text { Hydrophilic and low resistant; } \\
\text { high roughness with large surface area }\end{array}$ & Staphylococcus aureus & [8] \\
\hline Plastic (polypropylene) & $\begin{array}{l}\text { Hydrophobic and resistant; } \\
\text { low roughness of the surface }\end{array}$ & Listeria monocytogenes & [7] \\
\hline Silicone & $\begin{array}{l}\text { Highly hydrophobic and low resistant; } \\
\text { intermediate roughness of the surface }\end{array}$ & S. aureus & [8] \\
\hline
\end{tabular}

\section{Detection of biofilms on surfaces in the food industry}

The detection of microbial biofilms in the food processing environment is a difficult task, although experimental 
techniques can be used for assessing the adhesion, detachment, and biofilm formation ability of strains isolated from materials commonly used in the food industry [7, 8]. Initially, regular investigations of the prevalence and identification of pathogenic strains are required throughout the equipment and utensils in the food industry. To assess the biofilmformation ability of the isolates, static biofilm systems may be used in view of the simplicity of experimental procedures and the possibility of standardization of conditions [3]. To this end, Microtiter Plate (MTP)-based assays can be used for assessing the ability of selected microbial strains to produce biofilms in vitro and estimate their resistance to biocides [24]. In MTP assays, the biofilm can be formed and matured on the bottom or on the walls of the microplate wells. Crystal Violet (CV) staining is frequently used in MTP assays to quantitatively indicate the bacterial biomass but not the viable cells in the biofilm [25]. Moreover, it provides robust, low-cost experimental conditions for the evaluation of a high number of simultaneous variables for biofilm studies (e.g., several types of strains, biocides, and concentrations against them) [3]. However, the MTP assay is not suitable for the biofilm on other material surfaces, such as stainless steel, glass, and aluminum. In this case, biofilm quantification should be accomplished by plate count methods, along with visualization by scanning electron microscopy or confocal laser scanning microscopy [14, 24], among other techniques.

A number of microscopic techniques have also been used for the examination of microbial biofilm on surfaces, such as scanning electron microscopy [26-30], fluorescence microscopy [31-34], and confocal laser scanning [35-38]. Among the available techniques, LIVE/DEAD $®$ BacLight assay is one of the most used for assessing the viability of cells in the biofilm structure, based on two different nucleic acid binding stains. Thus, LIVE/DEAD assay can detect live or dead cells but not the biofilm biomass. The first dye (Syto9, which is green fluorescent) provides information on living cells since it is able to cross cell membranes and bind to DNA of both Gram-positive and Gram-negative bacteria. The second dye is the propidium-iodide (red fluorescent), which crosses only damaged membranes thus indicating only dead cells using a fluorescent optical microscopy [39]. However, the main limitation of this technique is the requirement of extensive observations representative sections of the sample [39], which provides only semi-quantitative results [12]. RNA-based qPCR has also been applied not only to quantify but also to characterize microbial interactions within dualspecies biofilms composed by Pseudomonas aeruginosa and S. aureus [40]. The qPCR method can evaluate specific gene expression along with the quantification of bacterial populations in dual-species biofilms when the profusion of gene transcription is calculated by normalization against ref mRNA [41]. The sensitivity of qPCR to quantify species with extremely low cell numbers may limit its ability to quantify less prevalent species in the community $[5,41]$.

\section{Surface cleaning and disinfection strategies for prevention of microbial biofilms}

Ideally, preventing biofilm formation seems more logical than removing it [5]. Therefore, the prevention of foodborne diseases that can be transmitted by surface contamination of equipment and utensils is based on the efficient reduction of pathogens by proper washing and disinfection by biocides [42,43]. In this context, regular and effective cleaning and disinfection procedures are fundamental to control pathogen dissemination on either industrial equipment or the food products themselves [44]. However, the effectiveness of a given hygienic method is dependent on the status of the residual material on the surface [24]. Additionally, improper cleaning procedures may convert the fouling layer from a readily removable form to one harder to remove, thus providing a permanent substrate for microbial biofilm formation [19].

Biofilm growth on surfaces in the food processing environment can also result in economic losses $[1,4,19]$ since they often require the suspension of manufacturing steps and additional labor for effective removal of biofilms by stringent cleaning and disinfection procedures [19,21]. Furthermore, the formation of microbial biofilms on the internal surface of thermal equipment such as pasteurizers and sterilizers may lead to corrosion of the material and to reduced efficiency of heat exchangers, thus causing huge losses for the food industry especially in smaller scale processing units $[45,46]$.

Most of the application guidelines of biocides used in the food industry, such as sodium hypochlorite, ammonium quaternary, and Peracetic Acid (PAA), have been developed for planktonic cells from microorganisms [47], although the great majority of microorganisms on surfaces live as adherent communities. In addition, the scientific literatures have already indicated that the bacterial cells living in biofilm communities may be up to 1,000 -fold more resistant to 
biocides, or sanitizers, than their respective planktonic cells $[10,48,49]$. In addition, the usual sanitizing procedures applied in food industries are not only fully effective on biofilm structures but can also induce the selection of phenotypes that are more resistant to biocides [5].

The effectiveness of sanitizers on bacterial reduction has many factors depending on the product type, target microorganisms, time interval between contamination and washing, and treatment time [14, 19]. The effective removal of microbial biofilms is possible depending on the type and composition of the food residue displayed on the surfaces, and the phenotypic and genotypic characteristics of microorganisms in the microbial community [5]. Furthermore, specific detergents and disinfectants in food industries should be selected according to their efficacy, safety, and ease of removal, as well as the possibility of generating sensory defects on the final products $[1,14,19]$. It has been reported that the efficacy of biocides against biofilms increases at higher concentrations and treatment times [10]. The effectiveness of a given biocide is usually demonstrated when it can reduce the counts of the targeted organism by at least $3 \log$ cycles (99.9\%) [50]. As an example, one of the most widely used sanitizers in the food industry is Peracetic Acid (PAA), which has proven to be effective on planktonic bacterial cells [51]. PAA is a strong biocide with a wide spectrum of antimicrobial activity that was introduced to wastewater treatment several years ago and is largely used in the food, beverage, and paper industries [1]. PAA is active in a wide range of temperatures $\left(0-25^{\circ} \mathrm{C}\right)$ and at $\mathrm{pH}$ values of 3.0 to 7.5 [52]. This compound has an important advantage when compared with chlorine and its derivate since PAA does not originate any mutagenic by-products at concentrations normally used for disinfection [52]. The mechanism of action of PAA against micro-organisms is based on the denaturation of proteins and enzymes, as well as increased cell wall permeability by oxidizing sulfhydryl and disulfide bonds [53]. Moreover, PAA is not affected by protein residues and decomposes into safe and environmentally friendly residues (acetic acid and hydrogen peroxide), which allows applications in food processing without risks of food contamination by toxic residues [32, 54].

There have been significant advances in the development of biocontrol methods, particularly with bacteriophages. Phages can affect bacterial biofilms by integrating into the bacterial genome thus affecting the biofilm formation, by promoting cell lysis in the biofilm by encoding lyase, or through phage enzymes that degrade extracellular polymers and destroy the polysaccharide matrix and proteins in the biofilm [55]. The use of competitive bacterial species also showed some promising results with the concept of using antagonist strains isolated from the production environment [56]. Bacteriocins and endolysins have also shown their ability to reduce established biofilms. The lysin PlyLM reduced the monolayer biofilms of L. monocytogenes to the same level as the application of lysozyme and proteinase K [57]. However, the sensory implications and the concentrations required for antimicrobial effects are major limiting factors for using these compounds as single biocontrol methods for application on food contact surfaces. Moreover, like other control methods, effectiveness can be affected by a variety of factors, including temperature and time, biofilms of one or more species, biofilm growth method, and surface matrix composition [57].

In addition to biological and/or chemical alternatives, physical-based processes such as pulsed-light or plasma treatments are promising technologies to reduce microbial contamination in the food industry. In particular, the plasma as the fourth state of matter can be generated by the ionization of several gases, including argon, helium, nitrogen, air, or oxygen alone or in mixtures. Plasmas are categorized into thermal or non-thermal, with Cold Plasma (CP) as one of the most studied, non-thermal technology aiming to decontaminate the microbial load surfaces of food products [58]. The main advantages of $\mathrm{CP}$ include the fact of being a chemical and water-free technology, and the possibility of openly and continuously operation at atmospheric pressure [59]. CP has been demonstrated to be effective for destroying or inactivate planktonic cells from bacteria, yeasts, and molds, as well as spores that are generally very difficult to inactivate using conventional methods [57]. Furthermore, previous studies have indicated the effectiveness of $\mathrm{CP}$ as an emerging technology for the treatment of microbial contaminations on food surfaces [52,60], opening new perspectives for tackling the microbial biofilm problem in the food industry. Further studies should determine the effectiveness of $\mathrm{CP}$ exposure times on biofilms formed by foodborne pathogens on surfaces under real conditions in food processing environments.

\section{Concluding remarks}

The importance of biofilms on surfaces in the food industries has been highlighted in several works, although 
the mechanisms involved in the formation of multiple species biofilms are not yet entirely understood. The microbial biofilms formed in food processing environments can be extremely resistant and complicated to eliminate, with negative consequences for public health. It is imperative to understand the interactions between bacteria and surfaces in specific food processing environments, and the impacts of bacteria associated with the surface on cleaning and disinfection, to provide more effective measures for preventing biofilm formation, biofilm removal, and preventive disinfection procedures. Therefore, the successful implementation of food standard programs is required to avoid food contamination by microbial biofilms. In this context, the correct application of quality tools, such as Sanitation Standard Operating Procedure and Hazard Analysis of Critical Control Points, along with complete and daily inspection of equipment and utensils, are of fundamental importance for the prevention of biofilm formation in food processing environments.

\section{Acknowledgements}

The authors thank the Conselho Nacional de Desenvolvimento Científico e Tecnológico (CNPq) for financial support and fellowship-Grant no. 306304/2017-1.

\section{Conflict of interest}

The authors declare that they have no conflicts of interest.

\section{References}

[1] Lee S, Cappato L, Corassin C, Cruz A, Oliveira C. Effect of peracetic acid on biofilms formed by Staphylococcus aureus and Listeria monocytogenes isolated from dairy plants. Journal of Dairy Science. 2016; 99: 2384-2390.

[2] Jahid I, Lee N, Kim A, Ha S. Influence of glucose concentrations on biofilm formation, motility, exoprotease production, and quorum sensing in Aeromonas hydrophila. Journal of Food Protection. 2013; 76: 239-247.

[3] Abdallah M, Chataigne G, Ferreira-Theret P, Benoliel C, Drider D, Dhulster P, et al. Effect of growth temperature, surface type and incubation time on the resistance of Staphylococcus aureus biofilms to disinfectants. Applied Microbiology and Biotechnology. 2014; 2597-2607.

[4] Oxaran V, Dittmann K, Lee S, Chaul L, Oliveira C, Corassin C, et al. Behavior of foodborne pathogens, $L$. monocytogenes and $S$. aureus, in mixed-species biofilm exposed to biocides. Applied and Environmental Microbiology. 2018; 84: 13-18.

[5] Magalhães R, Vieira T, Fernandes H, Melo A, Simões M, Sousa S. The Biofilms structural database. Trends in Biotechnology. 2020; 38: 937-940.

[6] Bridier A, Sanchez-Vizuete P, Guilbaud M, Piard J, Naïtali M, Briandet R. Biofilm-associated persistence of foodborne pathogens. Food Microbiology. 2015; 45: 167-178.

[7] Lee S, Barancelli G, Camargo T, Corassin C, Rosim R, Cruz A, et al. Biofilm-producing ability of Listeria monocytogenes isolates from Brazilian cheese processing plants. Food Research International. 2017; 91: 88-91.

[8] Lee S, Mangolin B, Gonçalves J, Neeff D, Silva M, Cruz A, et al. Biofilm-producing ability of Staphylococcus aureus isolates from Brazilian dairy farms. Journal of Dairy Science. 2014; 97: 1812-1816.

[9] Meira Q, Barbosa I, Athayde A, Siqueira-Júnior J, Souza E. Influence of temperature and surface kind on biofilm formation by Staphylococcus aureus from food contact surfaces and sensitivity to sanitizers. Food Control. 2012; 25: 469-475.

[10] Skowron K, Wałecka-Zacharska E, Grudlewska K, Gajewski P, Wiktorczyk N, Wietlicka-Piszcz M, et al. Disinfectant susceptibility of biofilm formed by Listeria monocytogenes under selected environmental conditions. Microorganisms. 2019; 7: 280-296.

[11] Köhler A, Rodloff A, Labahn M, Reinhardt M, Truyen U, Speck S. Evaluation of disinfectant efficacy against multidrug-resistant bacteria: A comprehensive analysis of different methods. American Journal of Infection Control. 2019; 47: 1181-1187.

[12] Lee S, Barancelli G, Corassin C, Rosim R, Coppa C, Oliveira C. Effect of peracetic acid on biofilms formed by L. monocytogenes strains isolated from a Brazilian cheese processing plant. Brazilian Journal of Pharmaceutical 
Sciences. 2017; 53: 1-7.

[13] Pakbin B, Didban A, Monfared K, Mahmoudi R, Peymani A, Modabber M. Antibiotic susceptibility and genetic relatedness of Shigella species isolated from food and human stool samples in Qazvin, Iran. BMC Research Notes. 2021; 14: 144.

[14] Dominciano L, Oliveira C, Lee S, Corassin C. Individual and combined antimicrobial activity of oleuropein and chemical sanitizers. Journal of Food Chemistry Nanotechnology. 2016; 2: 124-127.

[15] Di Ciccio P, Vergara A, Festino A, Paludi D, Zanardi E, Ghidini S, et al. Biofilm formation by Staphylococcus aureus on food contact surfaces: relationship with temperature and cell surface hydrophobicity. Food Control. 2015; 50: 930-936.

[16] Techer C, Jan S, Gonnet F, Grosset N, Gautier M, Baron F. Bacterial diversity on stainless steel surfaces of egg processing companies and potential of selected isolates to spoil liquid whole egg products. Journal of Applied Microbiology. 2019; 127: 1501-1510.

[17] Zhao X, Zhao F, Wang J, Zhong N. Biofilm formation and control strategies of foodborne pathogens: food safety perspectives. Trends in Food Science \& Technology. 2009; 20: 407-413.

[18] Dittmann K, Chaul L, Lee S, Corassin C, Oliveira C, De Martinis E, et al. Staphylococcus aureus in Some Brazilian Dairy Industries: Changes of Contamination and Diversity. Front Microbiol. 2017; 8: 1-12.

[19] Fagundes H, Corassin C, Tavolaro P, Oliveira C. Milk hygienic practices and occurrence of Staphylococcus aureus and Escherichia coli O157:H7 in small-scale dairy farms in São Paulo, Brazil. African Journal of Microbiology Research. 2012; 6: 5805-5808.

[20] Srey S, Jahid I, Ha S. Biofilm formation in food industries: a food safety concern. Food Control. 2013; 31 : 572585.

[21] Teh K, Flint S, Palmer J, Andrewes P, Bremer P, Lindsay D. Biofilm: An unrecognised source of spoilage enzymes in dairy products? International Dairy Journal. 2014; 34: 32-40.

[22] Vázquez-Sánchez D, Cabo M, Ibusquiza P, Rodríguez-Herrera J. Biofilm-forming ability and resistance to industrial disinfectants of Staphylococcus aureus isolated from fishery products. Food Control. 2014; 39: 8-16.

[23] Hamadi F, Asserne F, Elabed S, Bensouda S, Mabrouki M, Latrache H. Adhesion of Staphylococcus aureus on stainless steel treated with three types of milk. Food Control. 2014; 38: 104-108.

[24] Dominciano L, Lee S, Santello J, De Martinis E, Corassin C, Oliveira C. Effect of oleuropein and peracetic acid on suspended cells and mono-species biofilms formed by Staphylococcus aureus and Escherichia coli. Integrative Food, Nutrition and Metabolism. 2016; 3: 314-317.

[25] Stiefel P, Rosenberg U, Schneider J, Mauerhofer S, Maniura-Weber K, Ren Q. Is biofilm removal properly assesse? Comparison of different quantification methods in 96-well plate system. Applied. Microbiology Biotechnology. 2016; 100: 4135-4145.

[26] Bui L, Hoffmann P, Turnidge J, Zilm P, Kidd S. Prolonged growth of a clinical Staphylococcus aureus strain selects for a stable small-colony-variant cell type. Infection and Immunity. 2015; 83: 470-481.

[27] Casarin L, Brandelli A, Casarin F, Soave P, Wanke C, Tondo E. Adhesion of Salmonella Enteritidis and Listeria monocytogenes on stainless steel welds. International Journal of Food Microbiology. 2014; 191: 103-108.

[28] Prates D, Haubert L, Würfel S, Cavicchioli V, Nero L, Silva W. Listeria monocytogenes in dairy plants in Southern Brazil: Occurrence, virulence potential, and genetic diversity. Journal of Food Safety. 2019; 36: e12695.

[29] Jongsma M, Mei H, Atema-Smit J, Busscher H, Re Y. In vivo biofilm formation on stainless steel bonded retainers during different oral health-care regimens. International Journal of Oral Science. 2015; 7: 1-7.

[30] Souza E, Meira G, Barbosa I, Athayde A, Conceição M, Siqueira J. Biofilm formation by Staphylococcus aureus from food contact surfaces in a meat-based broth and sensitivity to sanitizers. Brazilian Journal of Microbiology. 2014; 45: 67-75.

[31] Jung Y, Choi J, Kim S, Lee J, Kwon S. Embedded biofilm, a new biofilm model based on the embedded growth of bacteria. Journal of Applied \& Environmental Microbiology. 2015; 81: 211-219.

[32] Lutskiy M, Katz S, Zhu N, Itsko M, Ronen Z, Arnusch C, et al. A microbiology-based assay for quantification of bacterial early stage biofilm formation on reverse-osmosis and nanofiltration membranes. Separation and Purification Technology. 2015; 141: 214-220.

[33] Sakimura T, Kajiyama S, Adachi S, Chiba K, Yonekura A, Tomita M, et al. Biofilm-forming Staphylococcus epidermidis expressing vancomycin resistance early after adhesion to a metal surface. BioMed Research International. 2015; 9: 43-46.

[34] Seyeux A, Zanna S, Allion A, Marcus P. The fate of the protective oxide film on stainless steel upon early stage growth of a biofilm. Corrosion Science. 2015; 91: 352-356. 
[35] Arias-Moliz M, Ordinola-Zapata R, Baca P, Ruiz-Linares M, García E, Duarte M, et al. Antimicrobial activity of chlorhexidine, peracetic acid and sodium hypochlorite/etidronate irrigant solutions against Enterococcus faecalis biofilms. International Endodontic Journal. 2014; 3: 345-349.

[36] Cárcamo-Oyarce G, Lumjiaktase P, Kümmerli R, Eberl L. Quorum sensing triggers the stochastic escape of individual cells from Pseudomonas putida biofilms. Nature Communications. 2015; 6: 5945.

[37] Quintas V, Prada-López I, Prados-Frutos J, Tomás I. In situ antimicrobial activity on oral biofilm: essential oils vs. 0.2\% chlorhexidine. Clinical Oral Investigations. 2015; 19: 97-107.

[38] Tamura N, Kira G, Patussi E, Donatti L, Svidzinski T. Adherence and biofilm formation of Fusarium oxysporum isolated from a corneal ulcer. Global Advanced Research Journal of Medicine and Medical Sciences. 2015; 4: 2834.

[39] Pantanella F, Valenti P, Natalizi T, Passeri D, Berlutti F. Analytical techniques to study microbial biofilm on abiotic surfaces: pros and cons of the main techniques currently in use. Annals of Occupational Hygiene. 2013; $25: 31-42$.

[40] Magalhães A, França Â, Pereira M, Cerca N. RNA-based qPCR as a tool to quantify and to characterize dualspecies biofilms. Scientific Reports. 2019; 9: 13639.

[41] Ghajarbeygi P, Mahmoudi R, Jafari Jozani R, Pakbin B. Qualitative investigation of meat species in meat products by real time polymerase chain reaction. Journal of Food Safety. 2018; 38: e12528.

[42] Li R, Kuda T, Yano T. Effect of food residues on efficiency of surfactant disinfectants against food related pathogens adhered on polystyrene and ceramic surfaces. LWT-Food Science and Technology. 2014; 57: 200-206.

[43] Neilluri D, Thota N. Challenges in emerging food-borne diseases. Food Safety and Preservation. 2018; 9: $231-268$.

[44] Jahid I, Lee N, Kim A, Ha S. Influence of glucose concentrations on biofilm formation, motility, exoprotease production, and quorum sensing in Aeromonas hydrophila. Jood of Food Protection. 2013; 76: 239-247.

[45] Pogiatzis T,Vassilis S, Mergulhão F, Wilson D. Choosing when to clean and how to clean biofilms in heat exchangers. Heat Transfer Engineering. 2015; 36: 676-684.

[46] Winkelstroter K, Teixeira F, Silva E, Alves V, De Martinis E. Unraveling microbial biofilms of importance for food microbiology. Microbial Ecology. 2014; 1: 35-46.

[47] Weber D, Rutala W, Sickbert-Bennett E. Use of germicides in health care setting is there a relationship between germicide use and microbial resistance: A concise review. American Journal of Infection Control. 2019; 47: 106109.

[48] Bonez P, Alves C, Dalmolin T, Agertt V, Mizdal C, Flores C, et al. Chlorhexidine activity against bacterial biofilms. American Journal of Infection Control. 2013; 1: 854-857.

[49] Pakbin B, Mahmoudi R, Mousavi S, Allahyari S, Amani Z, Peymani A, et al. Genotypic and antimicrobial resistance characterizations of Cronobacter sakazakii isolated from powdered milk infant formula: A comparison between domestic and imported products. Food Science \& Nutrition. 2020; 8: 6708-6717.

[50] Park E, Lee C, Bisesi M, Lee J. Efficiency of peracetic acid in inactivating bacteria, viruses, and spores in water determined with ATP bioluminescence, quantitative PCR, and culture-based methods. Journal of Water and Health. 2014; 12: 13-23.

[51] Fröhling A, Baier M, Ehlbeck J, Knorr D, Schlüter O. Atmospheric pressure plasma treatment of Listeria innocua and Escherichia coli at polysaccharide surfaces: inactivation kinetics and flow cytometric characterization. Innovative Food Science and Emerging Technologies. 2012; 13: 142-150.

[52] Patange A, Lu P, Boehm D, Cullen P, Bourke P. Efficacy of cold plasma functionalised water for improving microbiological safety of fresh produce and wash water recycling. Food Microbiology. 2019; 84: 103226.

[53] Luukkonen T, Pehkonen S. Peracids in water treatment: a critical review. Critical Reviews Environmental Science and Technology. 2017; 47: 1-39.

[54] Banach J, Veen H, Overbeek L, Zouwen P, Zwietering M, Fels-Klerx H. Effectiveness of a peracetic acid solution on E. coli reduction during fresh-cut lettuce processing at laboratory and industrial scales. International Journal of Food Microbiology. 2020; 321: 108537.

[55] Tian F, Li J, Nazir A, Tong Y. Bacteriophage-a promising alternative measure for bacterial biofilm control. Infection and Drug Resistance. 2021; 14: 205-217.

[56] Oliveira N, Martinez-Garcia E, Xavier J, Durham W, Kolter R, Kim W, et al. Biofilm formation as a response to ecological competition. PLoS Biology. 2015; 13: e1002191.

[57] Gray J, Chandry P, Kaur M, Kocharunchitt C, Bowman J, Fox E. Novel biocontrol methods for Listeria monocytogenes biofilms in food production facilities. Frontiers in Microbiology. 2018; 9: 605.

[58] Lacombe A, Niemira B, Gurtler J, Fan X, Sites J, Boyd G, et al. Atmospheric cold plasma inactivation of aerobic microorganisms on blueberries and effects on quality attributes. Food Microbiology. 2015; 46: 479-484. 
[59] Niemira B. Cold plasma decontamination of foods. Annual Review of Food Science and Technology. 2012; 3: 125142.

[60] Baier M, Foerster J, Schnabel U, Knorr D, Ehlbeck J, Herppich W, et al. Direct non-thermal plasma treatment for the sanitation of fresh corn salad leaves: evaluation of physical and physiological effects and antimicrobial efficacy. Postharvest Biology and Technology. 2013; 84: 81-87. 